\title{
Mimosine Toxicity in Broiler Chicks Fed Leucaena leucocephala Seed Powder
}

\author{
Yasuhiro KAMADA, Nobuaki OSHIRO, \\ Hirosuke OKU, Fujiya HONGO \\ and Isao CHINEN
}

Faculty of Agriculture, University of The Ryukyus, Nishihara-cho, Okinawa-ken 901-01

(Received July 4, 1996)

\begin{abstract}
Leucaena leucocephala has been utilized with limit as livestock feeds due to the existence of a toxic mimosine. So, it is necessary to induce mimosine toxicity to the experimental animals to study its cure and elucidation. The studies on inducing mimosine toxicity by feeding $L$. leucocephala seed powder to chicks were carried out. Chicks were fed normal diets with $0,10,15$ and $20 \%$ of $L$. leucocephala seed powder, and $1 \%$ crude mimosine for 12 days. Chicks fed toxic diets had decreased food intake and body weight gain, leg weakling symptom and enlargement of kidney. Mimosine was detected in the tissues of chicks fed the poisonous diets. Chicks orally administered crude mimosine were found to have alleviated the decrease of food intake and body weight gain. Chicks fed $15 \%$ seed powder diet for 12 days at $1 \sim 5$ weeks of age, respectively, had decreased food intake and body weight gain regardless of growing stages, but mimosine content in the tissues decreased with growing age. After feeding $15 \%$ seed powder diet for 12 days, chicks were fed a normal diet for 20 days. Food intake of the chicks increased from the 1st day when the diet was changed to normal diet. Mimosine considerably existed in the feather and thyroid gland on the 20th day, but disappeared in the kidney, serum, liver and excretion. So, male broiler chicks were found to be rapidly and easily induced to mimosine toxicity by feeding $15 \%$ L. leucocephala seed powder diet for 12 days, and stored mimosines in the tissues rapidly reduced by feeding a normal diet.
\end{abstract}

Anim. Sci. Technol. (Jpn.) 68 (2) : 121-130, 1997

Key words : Mimosine, Toxicity, Broiler chicks, Leucaena leucocephala seeds

Leucaena leucocephala, tropical and subtropical legume family, has been used as livestock feeds, owing to excellent growth effect and have their high contents of protein ${ }^{1.5 .10)}$, carotenoids $\mathrm{s}^{4,5,10)}$, vitamin $\mathrm{K}^{15)}$, xanthophylls ${ }^{4.5)}$ and minerals $4,5,10)$. The leaves and seeds of the plant, however, contain a toxic substance, mimosine, $\beta-\{N$ - $(3$-hydroxy-4-oxo- $1(4 H)$ pyridyl) $\}-\alpha$-aminopropionic acid, so that feeding large quantities of the plant to livestock leads to toxicity, such as alopecia, growth inhibition and enlargement of thyroid gland ${ }^{4-6.10)}$.

L. leucocephala has been restrictively utilized for this reason. In ruminants, however, no such toxicity appear because of the degradation of mimosine by ruminal bacteria ${ }^{1)}$. It has been reported that this detoxicification is attributed to a bacterial enzyme, cleaving mimosine to 3 -hydroxy- $4(1 H)$-pyridone $(3,4$ DHP), pyruvic acid and ammonia ${ }^{3,17}$, further 3 , 4-DHP to other compounds ${ }^{1-3}$. On the other hand, it has been generally assumed that mimosine is responsible for the protection of $L$. leucocephala from the attack of noxious insects ${ }^{9)}$. Noxious insects called Leucaena psyllids, however, has suddenly grown in large 
numbers in recent years ${ }^{12.16)}$. The Leucaena psyllids suck a sap in the plant, and kill the plant ${ }^{12,16)}$. It has been reported that the Leucaena psyllids also enzymatically degrade mimosine to $3,4-\mathrm{DHP}$, pyruvic acid and ammonia ${ }^{11}$.

In livestock except ruminants, this special toxicity still appear by feeding large quantity of the plant. Curing or elucidating of this toxicity has been very important problem and immediate study has been desired. Therefore, it is first necessary to induce mimosine toxicity to experimental animals. The purpose of this study, thus, is to establish experimental animal for curing or elucidating this toxicity when $L$. leucocephala seeds and leaves is used as livestock feeds. Generally speaking, mimosine should be administered to induce this toxicity, but preparation of mimosine takes time. So, studies on speedy and simple inducement of mimosine toxicity to 7 days old male broiler chicks fed commercial diet with L. leucocephala seed powder including higher mimosine and metabolism of mimosine in the tissues were carried out.

\section{Materials and Methods}

1. Material

1) Preparation of L. leucocephala seed powder

Brown ripe seeds were collected from bushes of L. leucocephala on the campus of the Faculty of Agriculture, University of The Ryukyus, from 1994 to 1995. The seeds were crushed by feeds smasher (Ikemoto Physico-chemical Industry), and $L$, leucocephala seed powder were prepared by passing crushed seeds through 20 mesh sieve to remove most outside shells of seed.

2) Preparation of crude mimosine

Crushed seeds $(350 \mathrm{~g})$ were boiled for $1 \mathrm{~h}$ in about $2400 \mathrm{ml}$ of distilled water to extract mimosine. Equivalent ethanol was added to the solution to precipitate impurities before the solution cooled, and then impuritics in the solu- tion were filtered by using suction filter. Other impurities in the filtrate were precipitated by storing in a freezer for $8 \mathrm{~h}$, and were removed by centrifuging $(5,000 \mathrm{rpm}, 20$ min). The supernatant solution was concentrated to about $100-150 \mathrm{~m} l$ by a rotary vacuum evaporator. Crude mimosine in the solution was precipitated by storing in a refrigerator. About $5 \mathrm{~g}$ of crude mimosine was prepared by centrifuging $(5,000 \mathrm{rpm}, 20 \mathrm{~min})$ the precipitate.

3) Experimental animais

Hatched Cobb strain male broiler chicks were obtained from Ishikawa Hatchery (Okinawan Animal Development Corporation), and previously kept for 1 week on commercial broiler feed (ME $3100 \mathrm{kcal} / \mathrm{kg}$, CP $23.5 \%$ ) from Ryukyu Kyodo Feed MFG. CO., Ltd.

2. Method

At first, necessary amount of L. leucocephala seed powder to induce mimosine toxicity in broiler chicks was decided. Seven days old chicks were fed ad libitum commercial diets with 10,15 and $20 \%$ (mimosine content $0.65,0.98$ and $1.30 \%$, respectively) of $L$. leucocephala seed powder for 12 days (Experiment I). In feeding commercial diet with crude mimosine, chicks were fed ad libitum commercial diet with $1 \%$ of crude mimosine which is equal to the mimosine content in $15 \%$ seed powder diet, and the toxicity of chicks fed $1 \%$ crude mimosine diet was compared with the toxicity of $15 \%$ seed powder diet (Experiment II). In order to compare the effect of feeding method, in oral crude mimosine administration, chicks were fed ad libitum commercial diet, and the same time were given crude mimosine by oral administration every day. The amount of crude mimosine orally administered was $250 \mathrm{mg}$ which is equal to $1 \%$ of the food intake (about $25 \mathrm{~g}$ ) of a 7 days old chick fed commercial diet (Experiment III). All experiments have control groups fed only commercial diet, and one group in all experiments contains 5 chicks. Body weight and food intake of the chicks were measured every day, and excretions were 
collected on the last day. Mimosine in the serum, liver, kidney, testis, thyroid gland, pectoral muscle, biceps femoris muscle, skin, feather and crown of slaughtered chicks were extracted, and its contents were determined by HPLC.

Secondly, relationship between growing stages and inducement of mimosine toxicity was examined. Chicks were fed $15 \%$ seed powder diets for 12 days from $1,2,3,4$ and 5 weeks of age, respectively, and measurements of food intake, body weight and mimosine content in the tissues were performed (Experiment IV).

Finally, after feeding $15 \%$ seed powder diet for 12 days to induce mimosine toxicity, chicks were fed a commercial diet for 20 days. The four chicks fed the commercial diet were slaughtered every four days, and mimosine content in the tissues was measured (Experiment V).

Ryukyu University's guide for the care and use of laboratory animals was followed in this study, so chicks were slaughtered by exhausting blood under the ether anesthesia. Chicks in all experiments were housed individually in controlled room temperature $\left(25 \pm 2^{\circ} \mathrm{C}\right)$ and lighting cycle for $12 \mathrm{~h}$, and were fed each diet by means of vessel for powder diet.

3. Determination of mimosine content in the tissues

One gram of each tissue except serum was homogenized in $6 \mathrm{ml}$ of $0.1 \mathrm{~N} \mathrm{HCl} \mathrm{solution,} \mathrm{and}$ $4.8 \mathrm{~m} l$ of $15 \%$ trichloroacetic acid (TCA) solution were added. The solution was allowed to stand for $20 \mathrm{~min}$, and followed by centrifugation at $12,000 \mathrm{rpm}$ for $20 \mathrm{~min}$ to remove the precipitates. The supernatant solution was filtered by filter for HPLC, and mimosine content was analyzed by injecting the filtrate (5-15 $\mu l)$ into HPLC. To $1.0 \mathrm{~m} l$ of serum, $0.8 \mathrm{~m} l$ of $15 \%$ TCA solution was directly added, and subsequent assay was applied as mentioned above. A Shimpack CLC-ODS $(150 \times 60 \mathrm{~mm})$ column was used in HPLC (Shimadzu LC-6 A) with a
UV $(250 \mathrm{~nm})$ detector as previously described ${ }^{7)}$.

\section{Statistical Analysis}

T-test analysis was applied throughout all experiments. The marks $\left({ }^{*}\right)$ in figures mean significant difference for control group at $\mathrm{p}<$ 0.01 .

\section{Results}

1. Mimosine content in L. leucocephala leaves and seeds

Mimosine content in leaves of $L$. leucocephala was $0.56 \% \mathrm{FM}$, but the content in seeds was $3.46 \% \mathrm{FM}$, showing that seeds contained about six times as much mimosine as leaves. The mimosine content in germs completely removed sced shells was $11.07 \%$ FM, which was three times higher than that in seeds. The mimosine content in the L. leucocephala seed powder removed most of seed shells by passing crushed seeds through 20 mesh sieve was $6.55 \%$ FM, which was twice as high as that of seeds. Therefore, seed powder containing relatively higher mimosine was used in this experiment. Purified rate of the crude mimosine was $87.2 \%$ FM (Table 1).

2. Mimosine toxicity in chicks fed $L$. leucocephala seed powder diet

In Experiment I, food intake and body weight gain smoothly increased daily in the control group, but decreased from the first day in the seed powder diet groups, and never increased. Therefore, extreme loss of appetite and growth depression appeared. Compared with the control group, food intake and body

Table 1. Mimosine content of young leaf, seed, germ, seed powder, and crude mimosine of $L$. leucocephala (\% FM)

\begin{tabular}{lc}
\hline \hline & Mimosine \\
\hline Young leaf & 0.56 \\
Seed & 3.46 \\
Germ & 11.07 \\
Seed powder & 6.55 \\
Crude mimosine & 87.20 \\
\hline
\end{tabular}




\section{KAMADA, OSHIRO, OKU, HONGO and CHINEN}

weight gain in the $10 \%$ seed powder diet group significantly decreased $(p<0.01)$ from the second day and the fourth day, respectively, and in both the 15 and $20 \%$ seed powder diet groups decreased from the first and third day, respectively. The 15 and $20 \%$ seed powder diet groups had remarkable loss of appetite (Fig. 1,2). Specific leg weakling symptom, sitting down and cramping, appeared from the fourth day in all the seed powder diet groups (Fig. 3). Mortality of the 15 and 20\% seed powder diet groups was 20 and $40 \%$, respectively. Besides, enlargement of kidney was

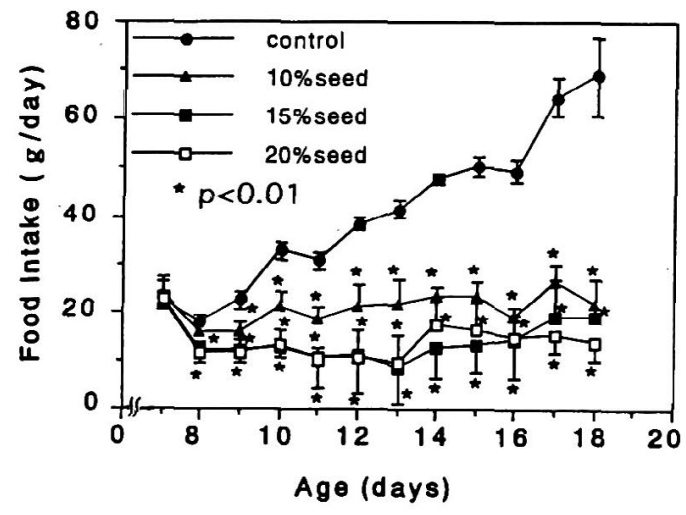

Fig. 1. Food intake of chicks fed commercial diets with $0,10,15$ and $20 \%$ L. leucocephala seed powder.

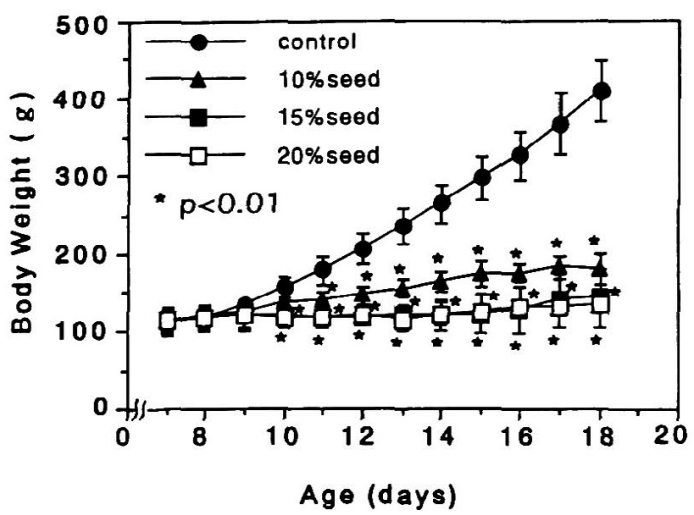

Fig. 2. Body weight of chicks fed commercial diets with $0,10,15$ and $20 \%$ L. leucocephala seed powder. observed in the seed powder diet groups (Fig. 4).

Mimosine was detected in all the tissues tested. Majority of the mimosine was found in the excretion. Rate of mimosine taken in the body was calculated to be about $56.1 \%$ from the amount of the daily excretion and food intake. The feather, kidney, skin, crown and testis had higher mimosine concentration in all the seed powder diet groups. Mimosine content in the tissues except the kidney and thyroid gland in the $15 \%$ seed powder diet group was higher than those in the $10 \%$ seed powder diet group (Table 2).

In Experiment II, food intake and body weight gain smoothly increased daily in the control group, but decreased from the first day in the $15 \%$ seed powder diet group and $1 \%$

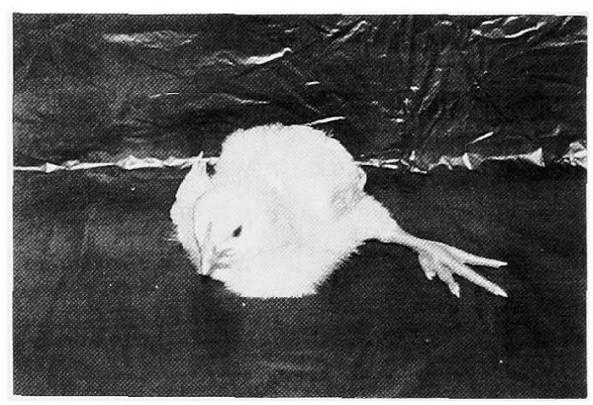

Fig. 3. Leg weakling symptoms of a chick induced by feeding $15 \%$ L. leucocephala seed powder diet.

A

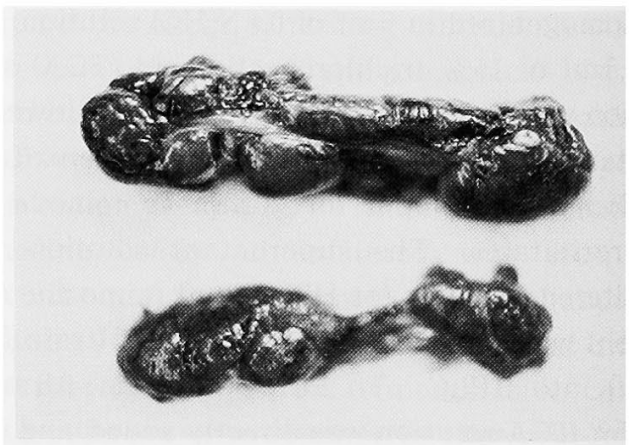

Fig. 4. Kidneys of chicks fed $15 \%$ L. leucocephala seed powder diet (A) and commercial $\operatorname{diet}(\mathrm{B})$. 
Mimosine Toxicity in Broiler Chicks

Table 2. Mimosine content in tissues of chicks fed commercial diet with 10,15 and $20 \%$ of $L$, leucocephala seed powder $(\mu \mathrm{g} / \mathrm{g})$

\begin{tabular}{lccc}
\hline \multicolumn{1}{c}{ Tissues } & $10 \%$ seed & $15 \%$ seed & $20 \%$ seed \\
\hline Feather & $213.6 \pm 54.74$ & $377.5 \pm 238.80$ & $303.4 \pm 40.05$ \\
Skin & $119.9 \pm 51.40$ & $241.0 \pm 55.13$ & $117.3 \pm 36.47$ \\
Kidney & $154.4 \pm 130.65$ & $142.1 \pm 99.66$ & $73.3 \pm 44.95$ \\
Biceps femoris muscle & $31.1 \pm 7.87$ & $54.5 \pm 19.28$ & $46.2 \pm 36.72$ \\
Pectoral muscle & $35.7 \pm 17.71$ & $75.5 \pm 25.07$ & $48.9 \pm 36.80$ \\
Serum & $27.2 \pm 15.56$ & $76.6 \pm 36.56$ & $64.8 \pm 18.24$ \\
Crown & $149.8 \pm 71.60$ & $289.6 \pm 277.65$ & $351.9 \pm 272.44$ \\
Testis & $143.2 \pm 54.20$ & $243.8 \pm 59.79$ & $221.3 \pm 57.69$ \\
Thyroid gland & $80.0 \pm 19.07$ & $74.2 \pm 32.88$ & $130.9 \pm 117.50$ \\
Liver & $20.2 \pm 19.85$ & $41.1 \pm 14.98$ & $48.5 \pm 5.55$ \\
Excretion & $24661.9 \pm 3560.02$ & $24359.6 \pm 2008.18$ & $23553.3 \pm 4008.73$ \\
\hline
\end{tabular}

Means \pm S.D.

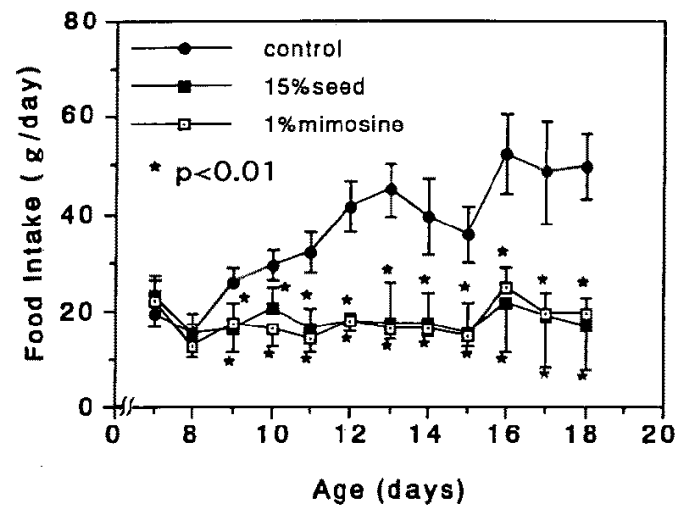

Fig. 5. Food intake of chicks fed commercial diets with $0,1 \%$ of crude mimosine and $15 \% \mathrm{~L}$. leucocephala seed powder.

crude mimosine diet group. Compared with the control group, food intake and body weight gain significantly decreased $(\mathrm{p}<0.01)$, in both the groups, from the third and sixth days, respectively (Fig. 5). Chicks (7 days of age) fed $1 \%$ crude mimosine diet showed the same toxicity and symptoms, such as extreme loss of appetite, growth depression and leg weakling. with chicks fed $15 \%$ seed powder diet, and the chicks had the same mimosine content in all the tissues except crown with chicks fed $15 \%$ seed powder diet.

3. Mimosine toxicity in oral crude mimo-

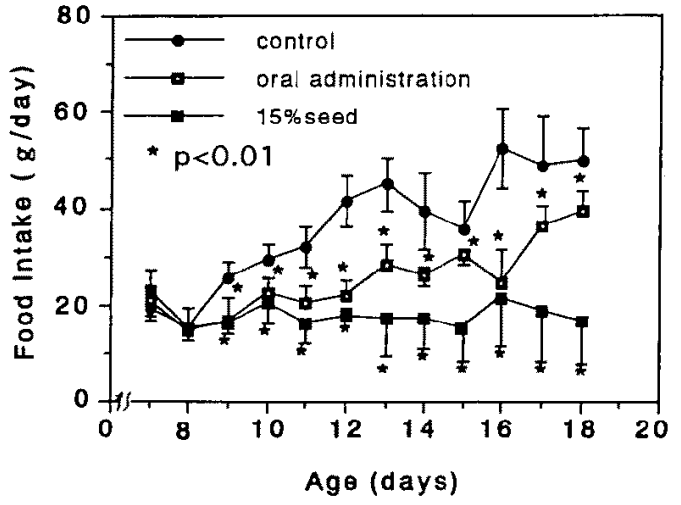

Fig. 6. Food intake of chicks fed commercial diet and at the same time crude mimosine (250 mg/day) given orally.

sine administration

In Experiment III, food intake and body weight gain smoothly increased daily in the control group, but decreased in the orally mimosine administered group. The decreases, however, were moderate, compared with the $15 \%$ seed powder group. Food intake and body weight gain significantly decreased $(p<$ 0.01 ) from the third and fifth day, respectively in the $15 \%$ seed powder diet group, and from the third and tenth day, respectively in the orally mimosine administered group (Fig.6). Mimosine contents in the skin, liver, kidney 


\section{KAMADA, OSHIRO, OKU, HONGO and CHINEN}

and thyroid gland in the orally mimosine administered group were almost the same with those in the $15 \%$ seed powder diet group.

4. Relationship between growing stages and inducement of mimosine toxicity

In Experiment IV, food intake decreased from the second day in all weeks of age, and significantly decreased $(p<0.01)$ from the fourth, sixth, third, second and third day from $1,2,3,4$ and 5 weeks of age, respectively. Body weight gain decreased in all weeks of age with decrease of food intake, and significantly decreased $(p<0.01)$ from the fifth, seventh, fourth, sixth and seventh day at 1,2,3,4 and 5 week days of age, respectively. Therefore, extreme loss of appetite and growth depression appeared at all weeks of age regardless of growing stages. Also, leg weakling symptom and enlargement of kidney were observed.

Mimosine concentration was constant in serum regardless of growth stages, but decreased in the feather, skin, thyroid gland, testis, crown, kidney, liver, pectoral muscle and biceps femoris muscle with growing stages. The ratios of mimosine concentrations at 5 weeks of age to those at 1 week of age were 2.0 , $3.7,4.7,12.6,13.5,17.5$ and $19.3 \%$ in the thyroid

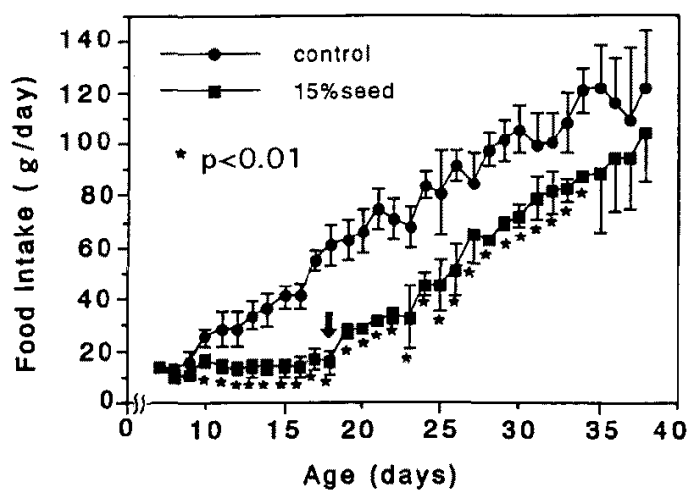

Fig. 7. Food intake of chicks fed commercial diet for 20 days after feeding commercial diet with $15 \%$ L. leucocephala seed powder for 12 days.

$\downarrow$ Means the frst day of diet change to commercial diet. gland, crown, testis, biceps femoris muscle, skin, liver and pectoral muscle, respectively.

5. Metabolism of mimosine in the chicks inducing mimosine toxicity

In Experiment $\mathrm{V}$, food intake and body weight gain of chicks fed $15 \%$ seed powder diet for 12 days decreased from the second day, and significantly decreased $(p<0.01)$ from the fifth and sixth day, respectively, compared with control group, and leg weakling symptom appeared. Food intake of the chicks rapidly increased from the first day when the diet was changed to commercial diet, and had no significant difference from that of the seventeenth day, compared with control group (Fig. 7). Body weight of the chicks had significant difference at all days fed commercial diet $(\mathrm{p}<$ 0.01 ), but gradually increased with the increase of food intake, and the amount of the increase was the same with that of the control group from the tenth day when the diet was changed to commercial diet (Fig. 8). Mimosine content in tissues suddenly decreased by feeding commercial diet, but still fairly large quantities of mimosine was found in the feather and thyroid gland even on the twentieth day, compared with other tissues. Relative mimosine values

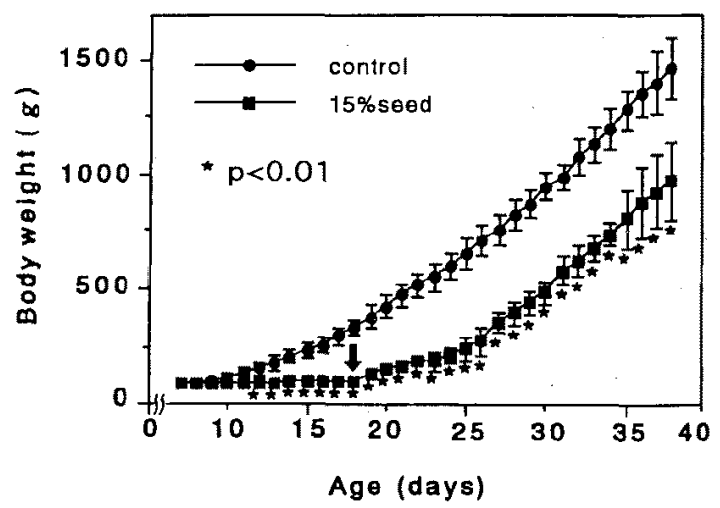

Fig. 8. Body weight of chicks fed commercial diet for 20 days after feeding commercial diet with $15 \% L$. leucocephala seed powder for 12 days.

$\downarrow$ Means the first day of diet change to commercial diet. 
Table 3. Mimosine content in tissues of chicks fed commercial diet for 20 days after feeding commercial diet with $15 \% \mathrm{~L}$. leucocephala seed powder for 12 days $(\mu \mathrm{g} / \mathrm{g})$

\begin{tabular}{lcccccc}
\hline \hline \multicolumn{1}{c}{ Tissues } & 0 day & 4 days & 8 days & 12 days & 16 days & 20 days \\
\hline Feather & $698.5 \pm 400.7$ & $434.5 \pm 99.0$ & $499.0 \pm 220.4$ & $198.5 \pm 66.9$ & $251.1 \pm 45.0$ & $81.4 \pm 45.5$ \\
Skin & $944.7 \pm 323.6$ & $89.9 \pm 68.9$ & $41.0 \pm 27.0$ & $18.6 \pm 16.5$ & $4.1 \pm 3.3$ & $10.9 \pm 4.1$ \\
Kidney & $91.2 \pm 62.9$ & N.D. & N.D. & N.D. & N.D. & N.D. \\
Biceps femoris muscle & $81.9 \pm 33.4$ & $19.4 \pm 3.4$ & $17.2 \pm 4.4$ & $13.4 \pm 8.8$ & $3.7 \pm 1.5$ & $0.2 \pm 0.1$ \\
Pectoral muscle & $92.4 \pm 37.6$ & $11.0 \pm 1.0$ & $10.0 \pm 1.1$ & $7.0 \pm 3.0$ & $5.3 \pm 2.0$ & $6.2 \pm 1.8$ \\
Serum & $69.6 \pm 53.3$ & N.D. & N.D. & N.D. & N.D. & N.D. \\
Crown & $215.9 \pm 20.7$ & $41.4 \pm 11.0$ & $54.0 \pm 25.1$ & $13.6 \pm 5.2$ & $10.4 \pm 4.2$ & $6.4 \pm 0.4$ \\
Testis & $191.0 \pm 66.0$ & $43.9 \pm 17.7$ & $49.2 \pm 24.9$ & $15.4 \pm 15.2$ & $9.4 \pm 6.5$ & $12.8 \pm 10.1$ \\
Thyroid gland & $101.4 \pm 58.1$. & $45.6 \pm 8.6$ & $80.5 \pm 56.1$ & $47.3 \pm 27.7$ & $24.9 \pm 20.0$ & $58.9 \pm 34.0$ \\
Liver & $43.1 \pm 31.0$ & N.D. & N.D. & N.D. & N.D. & N.D. \\
Excretion & $26182.6 \pm 4419.9$ & $386.0 \pm 309.0$ & N.D. & N.D. & N.D. & N.D. \\
\hline
\end{tabular}

Means \pm S.D.

of twentieth day to those of zero day before the changed to commercial diet in the feather and thyroid gland reduced to about 13 and $50 \%$, respectively, but mimosine was not found in the kidney, serum and liver from the fourth day, and in excretions from the eighth day.

Mimosine content in other tissues considerably decreased at the fourth day, but remained constant on the twentieth day. The ratios of mimosine concentrations at the fourth and twentieth day to those at zero day before the changed to commercial diet were 10.0, 12.0, 19.0, 24.0 and $45.0 \%$ on the fourth day, and $1.2,6.7,3.0$, 0.2 and $6.7 \%$ on the twentieth day in the skin, pectoral muscle, crown, biceps femoris muscle and testis, respectively (Table 3 ).

\section{Discussion}

Chicks fed $L$. leucocephala sced powder dict had extreme loss of appetite, growth depres. sion, specific leg weakling symptom, sitting down and cramping, and an accumulated mimosine in various tissues. Chicks fed $1 \%$ crude mimosine diet showed the same extent of toxicity with chicks fed $15 \%$ seed powder diet. Therefore, it was found that the toxicity was caused by mimosine. Mimosine content in the tissues and mortality decrease corresponded with growing stages, so it seems that the chick's resistance against mimosine toxicity gets gradually high with chronological age.

In chicks fed ad libitum L. leucocephala seed powder diet or crude mimosine diet, mimosine was detected in the serum, liver, kidney, testis, thyroid gland, pectoral muscle, biceps femoris muscle, skin, feather and crown. Especially, feather, skin and kidney had higher mimosine concentration. Sahlu et al. ${ }^{(4)}$ reported that mimosine was found in the serum, liver and kidney of goats performed the intravenous infusion of mimosine, but not found in the spleen, heart, lung and muscle. In the present experiment, however, mimosine was detected in the muscle of chicks fed seed powder diet. Food intake of chicks fed ad libitum $1 \%$ mimosine diet or $15 \%$ seed powder diet was $15-20 \mathrm{~g} /$ day, so the amount of ingested mimosine was calculated at about $200 \mathrm{mg} /$ day, and the mcasured dry excretion ( $3.3 \mathrm{~g} /$ day) included mimosine $(80$ $\mathrm{mg} /$ day). The absorbed mimosine content, therefore, was $120 \mathrm{mg} /$ day. Besides, the average of body weight was $0.123 \mathrm{~kg}$, so the amount of ingested mimosine per metabolic body size was calculated at $576.9 \mathrm{mg} \cdot \mathrm{kg} \mathrm{BW}^{-0.75} / \mathrm{day}$. In the report of Sahlu et $a l^{14)}$, however, goats were given $200 \mathrm{mg} \cdot \mathrm{kg} \mathrm{BW}^{-0.75} /$ day of mimosine by intravenous infusion. Therefore, the difference in results may be caused by the different 


\section{KAMADA, OSHIRO, OKU, HONGO and CHINEN}

amount of mimosine given to the animals. On the other hand, Sahlu et al. ${ }^{(4)}$ used goats as experimental animals, but the authors used broiler chicks, so the difference in results may be brought by the difference in animal species.

On the other hand, Sahlu et al. ${ }^{14)}$ reported that mimosine content $(57.2 \mu \mathrm{mol} / \mathrm{g})$ in the kidney was higher than mimosine content (25.6 $\mu \mathrm{mol} / \mathrm{g})$ in the liver. In this experiment, mimosine content $(91.2 \mu \mathrm{g} / \mathrm{g})$ in the kidney of chicks fed $15 \%$ seed powder diet was higher than that $(43.1 \mu \mathrm{g} / \mathrm{g})$ in the liver as shown in Table 3 . At this point, our results agreed with their results.

Chicks inducing mimosine toxicity were fed a commercial diet for 20 days, and the disappearance of mimosine in the tissues was detected. Consequently, mimosine in the feather and thyroid gland was detected even on the twentieth day but not in other tissues or if detected, in an extremely small quantity. It seemed that mimosine may not be accumulated, and may be degraded or excreted in the tissues except in the feather and thyroid gland. A large quantity of mimosine in chicks inducing mimosine toxicity were found in the excretion.

Whon seed powder diet was changed to commercial diet, mimosine was not detected in the excretions from the eighth day, and mimosine in the skin, biceps femoris muscle, pectoral muscle, crown and testis slowly decreased even from the eighth day. Therefore, mimosine in the tissues may not be excreted but metabolized. Mimosine in the feather may be excreted by alopecia because alopecia sometimes appeared. Mimosine concentration in the same tissues varied in different experiments, so various capability of degradation or excretion of mimosine in the tissues may cause different mimosine concentration in the tissues.

Feeding ad libitum 10, 15 and $20 \%$ seed powder diets (mimosine content 0.65, 0.98, $1.30 \%$, respectively) or $1 \%$ crude mimosine diet for 12 days, chicks (7 days of age) had an extreme decrease in the food intake. Reddy et al. ${ }^{13)}$ reported that broiler chicks (10 days of age) fed ad libitum 10 and $15 \%$ L. leucocephala seed diet (mimosine content 0.44 and $0.88 \%$ ) for 35 days decreased in food intake and body weight gain. Our result considerably agreed with their result.

Hussuian et $a l^{8)}$, however, reported that in broiler chicks (1 day of age) fed ad libitum 15\% $L$. leucocephala leaf meal diet for 35 days, there were no significant differences in the body weight gain and food intake, compared with the control group. This result was different from our result. We used mimosine seeds, but they used the leaves. Therefore, this result may be brought by the difference of mimosine content because mimosine content in the leaves is different from that in the seeds as shown in Table 1.

Chicks fed ad libitum 15\% seed powder diet decreased in food intake. On the other hand, when chicks were fed ad libitum commercial diet and at the same time $250 \mathrm{mg} /$ day of crude mimosine directly given in the throat by a spoon without touching the sense organs of taste and smell, the decreases in the food intake of the chicks were alleviated. Besides, when chicks induced mimosine toxicity were fed a commercial diet, the food intake of the chicks did not decrease. These results suggested that mimosine is odorless to human beings, but it might have special a taste or smell avoided by chicks.

\section{Acknowledgments}

We are deeply grateful for the generous gifts of chicks as experimental animais and commercial diet from Okinawan Animal Development Corporation and Ryukyu Kyodo Feed MFG. CO., Ltd., respectively.

\section{References}

1) Allison MJ, Hammond AC, Jones RJ. Detection of ruminal bacteria that degrade toxic 
dihydroxypridine compounds produced from mimosine. Appl. Env. Micrabiol., 56 : 590-594. 1990.

2) Allison MJ, Mayberry WR, Mcsweeney CS, Stahl DA. Synergistes jonesii, gen. nov., sp. nov., A rumen bacterium that degrades toxic pridinediols. System. Appl. Microbiol., 15 : $522-$ 529. 1992.

3) Bello MGD, Stewart CS. Characteristics of a rumen clostridium capable of degrading mimosine, $3(\mathrm{OH})-4(1 \mathrm{H})$-pridone and 2,3 dihydroxypridine. System. Appl. Microbiol, 14: 67-71. 1991.

4) D'Mello JPF, Taplin DE. Leucaena leucocephala in poultry diets for the tropics. World Rev, Anim. Prod., 14:41-47. 1978.

5) D'Mello JPF, Acamovic T. Leucaena leucocephala in poultry nutrition -A review. Anim. F. Sci. Tech., 26 : 1-28. 1989.

6) Gray SG. Tropical pasture species review. Tropical Grasslands, 2 : 19-30. 1968.

7) Hongo F, Tanaka A, Kawashima $Y$, Tawata $S$, Sunagawa $K$. The effects of various kinds of mimoisne-reduced Leucaena meal on rats. Jpn. J. Zootech. Sci., $59: 688-700.1988$.

8) Hussain J, Reddy PVVS, Reddy VR. Utilization of Leucaena meal by broilers. British Poultry Sci., 32 : 131-137. 1991.

9) Ishaaya I, Hirashima A, Yablonskei S, Tawata $\mathrm{S}$, Eto M. Mimosine, a nonprotein amino acid, inhibits growth and enzyme systems in Tribolium castaneum, Pesticide Biochem.
Physiol., $39:$ 35-42. 1991.

10) Jones RJ. The value of Leucaena leucocephala as a feed for ruminants in the tropics. World Anim. Rev., 31 : 13-23. 1979.

11) Kamada $Y$, Oshiro $N$, Oku $H$, Hongo $F$, Chinen I. Degradation of toxic mimosine by a hydrolytic enzyme of Leucaena psyllids (jumping plant lice). Biosci. Biotech. Biochem., 60 : 351-352. 1996.

12) Mitchell WC, Douglas FW. Spread of the Leucaena psyllid: Heteropsylla cubana in tha Pacific. Leucaena Research Reports, 7:6-8. 1986.

13) Reddy PVVS, Reddy VR, Ahmed N, Sharif SA. Nutritive value and utilization of subabul seed in broiler diets. Indian Vet. J., 72 : 143-145. 1995.

14) Sahlu T, Puchala R, Reis PJ, Davis JJ, Tesfai K, Fernandez JM, Millamena AA. Technical note : Tissue Residues of mimosine and 2,3 dihydroxypridine after intravenous infusion in goats. J. Anim. Sci., 73 : 172-176. 1995.

15) Shintoon C, Ross E. Comparative vitamin $K$ activity of dehydrated alfalfa and Leucaena leucocephala meal. Poult. Sci., 44: : 972-974. 1966.

16) Sorenson CT, James LB. Newly introduced psyllid in Hawaii injurious to Leucaena leucocephala. Leucaena Research Reports, 5 : 91-93. 1984.

17) Tangendjaja B, Hogan JP, Wills RBH. Degradation of mimosine by rumen contents : effect of feed composition and Leucaena substrates. Aust. J. Agric. Res., 34 : 289-293. 1983. 


\title{
ギンネム種子粉末を給与したブロイラー雛 に抢けるミモシン中毒症
}

\author{
鉡田靖弘・大城伸明・屋 㕕典・本郷富士弥・知念 功 \\ 琉球大学農学部, 沖縄県西原町 903-01
}

\begin{abstract}
ギンネムには毒性物質ミモシンが存在するため, 家畜に多量給与するとミモシン中㫱症を引き起こす ので，飼料としては制限給与している，このミモシン中毒症の治療，解明を行うためには契験動物にそ

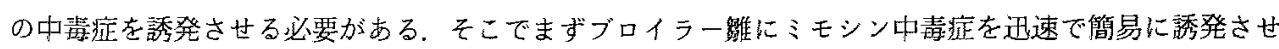

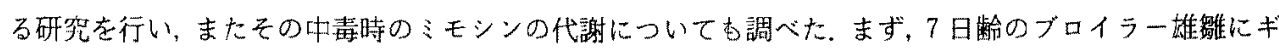

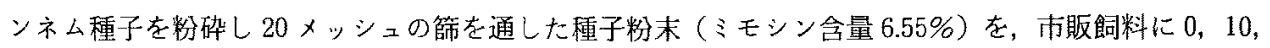
$15,20 \%$ 添加し各々 12 日間自由給与した，その結果，各種子粉末飼料群では食欲不振，体重增加の減少 がみられ，更に座り込み，足をけいれんさせる特異的な脚弱症状，扔よび督膱の肥大化がみられた。 ま た各組織でミモシンが検出され，特に羽毛，皮膚㧍るび留蔵で高い値が得られた、更に $1 \%$ 粗ミモシン 飼料を自由給与すると，15\%種子㸮末飼料給与時と全く同程度の中毒掟が喼められミモシン中毒症と断 定された．次に粗ミモシンを $250 \mathrm{mg} /$ 日，経口投与しながら市販飼料を給与すると，食欲不振と体重増 加の減少は緩和した．しかし，各組織中でのミモシン含量は $15 \%$ 種子粉末飼料給与と同様に存在した。 次に加龄とミモシン中毒症との関係を調べた，1，2，3，4 および5週龄で $15 \%$ 種子粉末飼料を 12 日間 給与すると，食欲不振，体重增加の減少は加齢に関係なく見られたが，組織中のミモシン含量は加踰に 伴って隇少した，最後に，ミモシン中毒症の踓に市販飼料を20日間給与し4日ごとに屠殺し，体内での ミモシンの代謝を調べた，その結果，まず市販飼料を給与した初日から食欲が回復し，採食量は市販飼 料給与後 17 日目で対然群と有意差が認められなくなった。それに伴って体重も增加した。 また各組織の

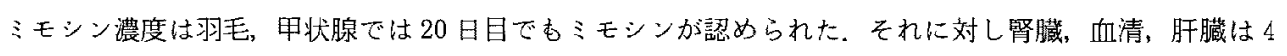
日目加ら，総排泄物は 8 日目加ら検出さ扎ななった，皮膚，筋肉，冠，精巣は20日目でま極少量のミ モシンが検出された。

日畜会報, $68(2) ： 121-130,1997$ 